DISCLAIMER

This report was prepared as an account of work sponsored by an agency of the United States Government. Neither the United States Government nor any agency Thereof, nor any of their employees, makes any warranty, express or implied, or assumes any legal liability or responsibility for the accuracy, completeness, or usefulness of any information, apparatus, product, or process disclosed, or represents that its use would not infringe privately owned rights. Reference herein to any specific commercial product, process, or service by trade name, trademark, manufacturer, or otherwise does not necessarily constitute or imply its endorsement, recommendation, or favoring by the United States Government or any agency thereof. The views and opinions of authors expressed herein do not necessarily state or reflect those of the United States Government or any agency thereof. 


\section{DISCLAIMER}

Portions of this document may be illegible in electronic image products. Images are produced from the best available original document. 


\title{
ANISOTROPIC YIELDING OF ROCKS AT HIGH TEMPERATURES AND PRESSURES
}

\author{
Annual Progress Report, $1988-1989$ \\ by
}

\section{A. K. Kronenberg}

J. E. Russell

and

N. L. Carter

November 30, 1989

\section{Center for Tectonophysics \\ Texas Engineering Experiment Station The Texas A\&M University System}

\section{DISCLAIMER}

This report was prepared as an account of work sponsored by an agency of the United States Government. Neither the United States Government nor any agency thereof, nor any of their employees, makes any warranty, express or implied, or assumes any legal liability or responsibility for the accuracy, completeness, or usefulness of any information, apparatus, product, or process disclosed, or represents that its use would not infringe privately owned rights. Reference herein to any specific commercial product, process, or service by trade name, trademark, manufacturer, or otherwise does not necessarily constitute or imply its endorsement, recommendation, or favoring by the United States Government or any agency thereof. The views and opinions of authors expressed herein do not necessarily state or reffect those of the United States Government or any agency thereof. 


\section{TABLE OF CONTENTS}

\section{INTRODUCTION}

\section{MANUSCRIPTS IN PRESS OR SUBMITTED}

Mechanical Anisotropy of Gneiss: Yield Criterion and Textural Sources of Directional Behavior

Basal Slip and Mechanical Anisotropy of Biotite

Mechanisms of Fracture Propagation in Experimentally Extended

Sioux Quartzite

Control of Fluids on Deformation of Rocks

A Material Model for Avery Island Rocksalt

Triaxial-compression Tests on Rocksalt at Temperatures from $50^{\circ}$

to $200^{\circ} \mathrm{C}$ and Strain Rates from $10^{-4}$ to $10^{-9} / \mathrm{s}$

\section{ONGOING RESEARCH}

Deformation of Biotite Schist

Deformation of Westerly Granite

Deformation of Bedded Rocksalt

Abstracts

Students Supported 


\section{INTRODUCTION}

This progress report for the project entitled "Anisotropic Yielding of Rocks at High Temperatures and Pressures" presents:

a summary of research accomplished since April 15, 1987 funded by the Department of Energy (grant no. DE-FG05-87ER13711) at the Center for Tectonophysics under the direction of Drs. Andreas Kronenberg and James E. Russell.

A renewal proposal to (a) investigate the mechanical properties and (b) model the mechanical responses to sediment loading of two weak and impermeable sedimentary rock types, shale and rocksalt has been submitted under a separate cover.

Our summary of research accomplishments since the initiation of this grant includes six manuscripts in press or submitted to referred journals and monographs which have resulted from research funded in full or in part by the Department of Energy. We also provide a list of abstracts and brief descriptions of ongoing research on schist, granite, and bedded rocksalt, the results of which have yet to be published.

\section{MANUSCRIPTS IN PRESS OR SUBMITTED}

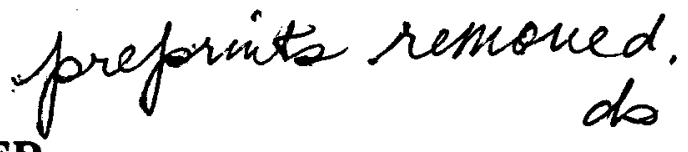

Manuscripts in press or submitted for publication in the last three-year project period include:

Gottschalk, R. R., A. K. Kronenberg, J. E. Russell, and J. Handin, Mechanical anisotropy of gneiss: yield criterion and textural sources of directional behavior, L. Geophys. Res. (submitted).

Kronenberg, A. K., S. H. Kirby, and J. Pinkston, Basal slip and mechanical anisotropy of biotite, L. Geophys. Res. (submitted).

Mardon, D., A. K. Kronenberg, J. Handin, M. Friedman, and J. E. Russell, Mechanisms of fracture propagation in experimentally extended Sioux quartzite, Tectonophysics (submitted).

Carter, N. L., A. K. Kronenberg, J. V. Ross, and D. V. Wiltschko, Control of fluids on deformation of rocks, in: Deformation Mechanisms, Rheology and Tectonics, edited by $R$. J. Knipe and E. H. Rutter, University of Leeds (submitted).

Russell, J. E., N. L. Carter, and S. C. Walker, A material model for Avery Island rocksalt, in: The Brittle-Ductile Transition in Rocks", The Heard Volume", Am. Geophys. Union Monograph, (in press).

Horseman, S. T., and J. Handin, Triaxial-compression tests on rocksalt at temperatures from $50^{\circ}$ to $200^{\circ} \mathrm{C}$ and strain rates from $10^{-4}$ to $10^{-9} / \mathrm{s}$, in: The Brittle-Ductile Transition in Rocks, "The Heard Volume", Am. Geophys. Union Monograph, (in press). 
Kronenberg, A. K., S. H. Kirby, and J. Pinkston, Basal slip and mechanical anisotropy of biotite, L. Geophvs, Res. (submitted).

Mardon, D., A. K. Kronenberg, J. Handin, M. Friedman, and J. E. Russell, Mechanisms of fracture propagation in experimentally extended Sioux quartzite, Tectonophysics (submitted).

Carter, N. L., A. K. Kronenberg, J. V. Ross, and D. V. Wiltschko, Control of fluids on deformation of rocks, in: Deformation Mechanisms, Rheology and Tectonics, edited by $R$. J. Knipe and E. H. Rutter, University of Leeds (submitted).

Russell, J. E., N. L. Carter, and S. C. Walker, A material model for Avery Island rocksalt, in: The Britrle-Ductile Transition in Rocks", The Heard Volume", Am. Geophys. Union Monograph, (in press).

Horseman, S. T., and J. Handin, Triaxial-compression tests on rocksalt at temperatures from $50^{\circ}$ to $200^{\circ} \mathrm{C}$ and strain rates from $10^{-4}$ to $10^{-9} / \mathrm{s}$, in: The Brittle-Ductile Transition in Rocks, "The Heard Volume", Am. Geophys. Union Monograph, (in press). 
We expect to complete two more manuscripts within the year, one on our continuing work on biotite schist and another on the forms of anisotropic yield criteria and their application to data acquired previously for slates and phyllites. We have completed experiments on Westerly granite, our isotropic end-member for comparison with results obtained for Four-Mile gneiss. However, the results for schist are surprising in several respects and we propose to continue our studies of micarich metamorphic rocks, treating these as coarse-grained analogues to fine-grained, clay-rich shales. As a means of summarizing our work, we include those manuscripts that have been completed and submitted for publication during the current funding period, followed by brief descriptions of our ongoing studies and unpublished results. 


\section{ONGOING RESEARCH}

\section{Deformation of Biotite Schist}

The experimental results we have obtained on Four-Mile gneiss have demonstrated that the yield behavior of quartzo-feldspathic rocks containing only a small percentage $(10 \%)$ of mica can be markedly anisotropic, provided the mica minerals exhibit a strong crystallographic preferred orientation. Samples of gneiss oriented such that resolved shear stresses on the foliation plane are large are considerably weaker than granites of similar grain size and composition, and this weakness is attributed to enhanced nucleation of microcracks in quartz and feldspar adjacent to mica grains that are suitably oriented for slip. We expect the yield behavior of rocks containing a higher proportion of phyllosilicates to be influenced by the strongly anisotropic nature of these minerals as well, although the strengths, temperature and pressure dependencies, and flow-controlling mechanisms in such rocks may be significantly different.

Constant strain rate and strain rate-stepping experiments have been performed on oriented samples of a fine-grained schist (Idaho County, Idaho) rich in biotite (>75\%) with 10-20\% epidote and several percent chlorite and feldspar. The starting material exhibits a well-defined, near-planar foliation and a consistent mesoscopic lineation. It lacks distinct segregation bands at this handspecimen scale; however, its distribution of biotite and epidote is somewhat heterogeneous at the thin section scale with millimeter-scale layers of nearly pure $(>95 \%)$ biotite alternating with zones which contain up to $50 \%$ epidote. The epidote-rich zones are somewhat finer grained, and preferred orientations of biotite appear to be weaker within them (Fig. 1). Subtle color differences between these alternating layers define the mesoscopic foliation within the rock. Compression experiments have been performed on samples cored parallel, perpendicular, and at $45^{\circ}$ to foliation at $25^{\circ} \leq \mathrm{T} \leq$ $400^{\circ} \mathrm{C}, 50 \leq \mathrm{P}_{\mathrm{c}} \leq 300 \mathrm{MPa}$, and $10^{-4} \leq \dot{\varepsilon} \leq 10^{-6} \mathrm{~s}^{-1}$.

Results for Four-Mile gneiss and previous schist experiments (Borg and Handin, 1966) suggest that the experiments we performed on the biotite schist would capture its maximum strength anisotropy. To our surprise, however, the experimental data do not reveal any significant strength differences associated with differing orientations at any experimental conditions tested. Plots of differential stress versus axial strain are presented in Figure 2 and compared with results for biotite single crystals in Figure 3. Each sample showed an initial elastic response, followed by a short period of rapid yielding within the first $2 \%$ strain. Experiments loaded at $45^{\circ}$ to foliation and lineation generally showed a more sharply defined yield point than those loaded perpendicular to foliation. Only one experiment (at the lowest confining pressure) exhibited a sudden stress drop after the yield point associated with the onset of a macroscopic brittle fracture; all other experiments accommodated the total shortening imposed at constant differential stresses (within 20 percent of 


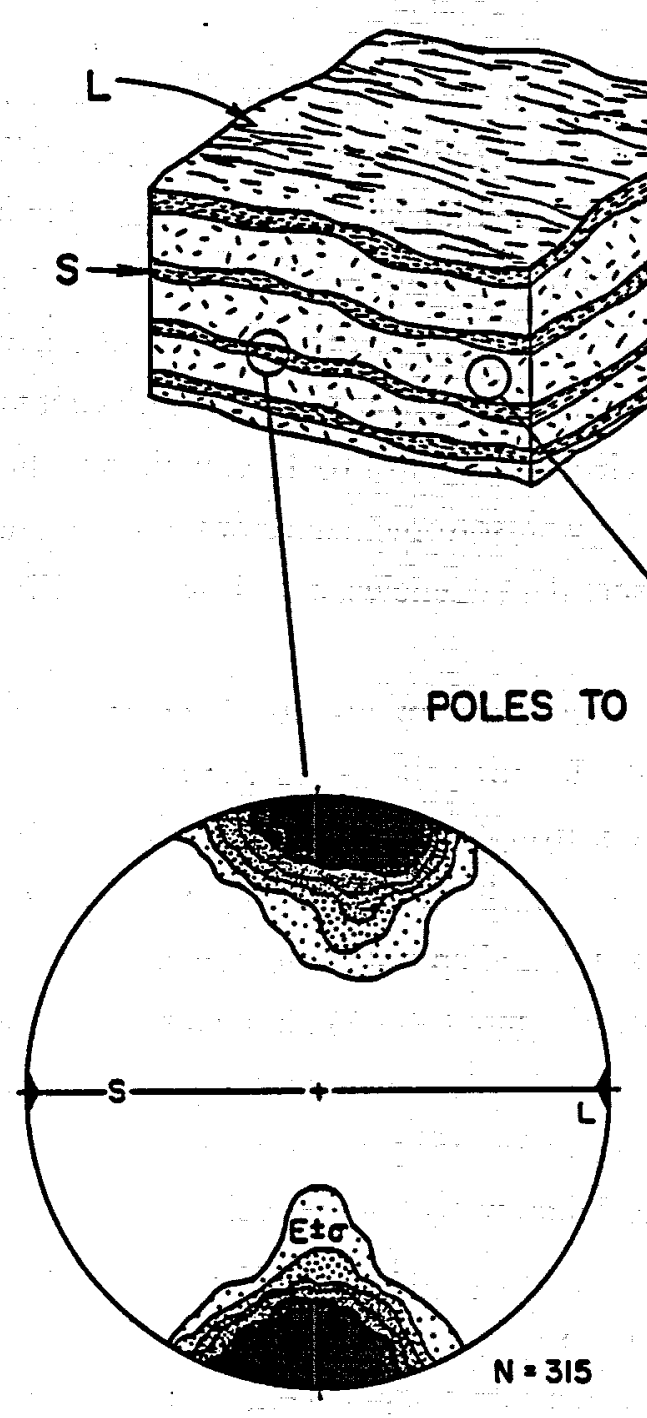

Kamb Contours $=2,4,6,8,10,12 \sigma$ Moximum $=28 \sigma$

\begin{tabular}{|c|c|}
\hline $\begin{array}{l}\text { Biotite } \\
\text { Epidose } \\
\text { Feldspor } \\
\text { Chlorite } \\
\text { Sphene }\end{array}$ & $\begin{array}{l}89 \\
9 \\
1 \pm \% \\
1 \pm \\
<1\end{array}$ \\
\hline
\end{tabular}

\begin{tabular}{|c|c|}
\hline $\begin{array}{l}\text { Biotite } \\
\text { Epidote } \\
\text { Feldspor } \\
\text { Chlorite } \\
\text { Sohene }\end{array}$ & $\begin{array}{l}68 \\
27 \\
3 \pm \% \\
2 \pm \\
<1\end{array}$ \\
\hline Sohene & $<1$ \\
\hline
\end{tabular}

DIOTITE $\{001\}$

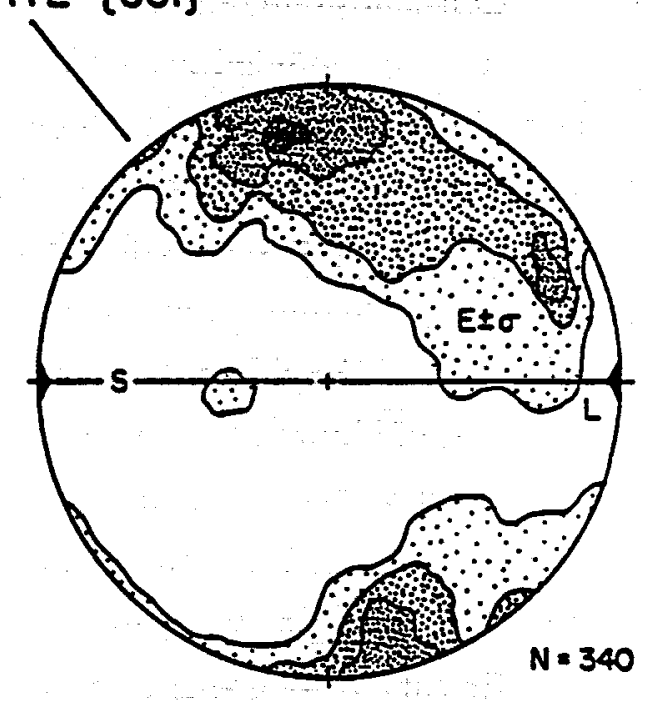

Kamb Contours $=2,4,6,8 \sigma$ Moximum $=8 \sigma$

$E=$ Expected Volue for Rondom Distribution

Figure 1. Finely dispersed segregation bands of biotite schist starting material. Seams rich in biotite parallel the mesoscopic foliation plane and exhibit strong crystallographic preferred orientations. Preferred orientations of micas within the remaining material are not nearly as strong. 
S.A. $S, L=80 / P C=200 \mathrm{MPa}$

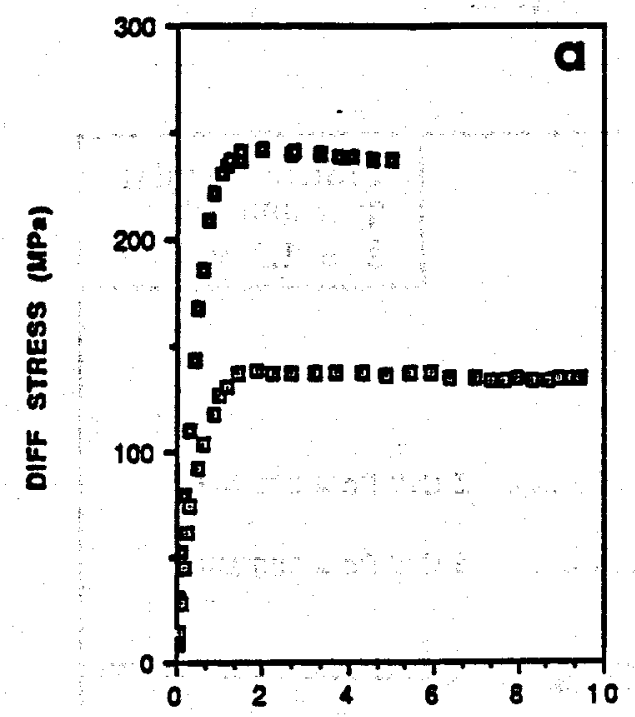

S.A. $\times$ S,LE $90 / \mathrm{PC}=300 \mathrm{MPa}$

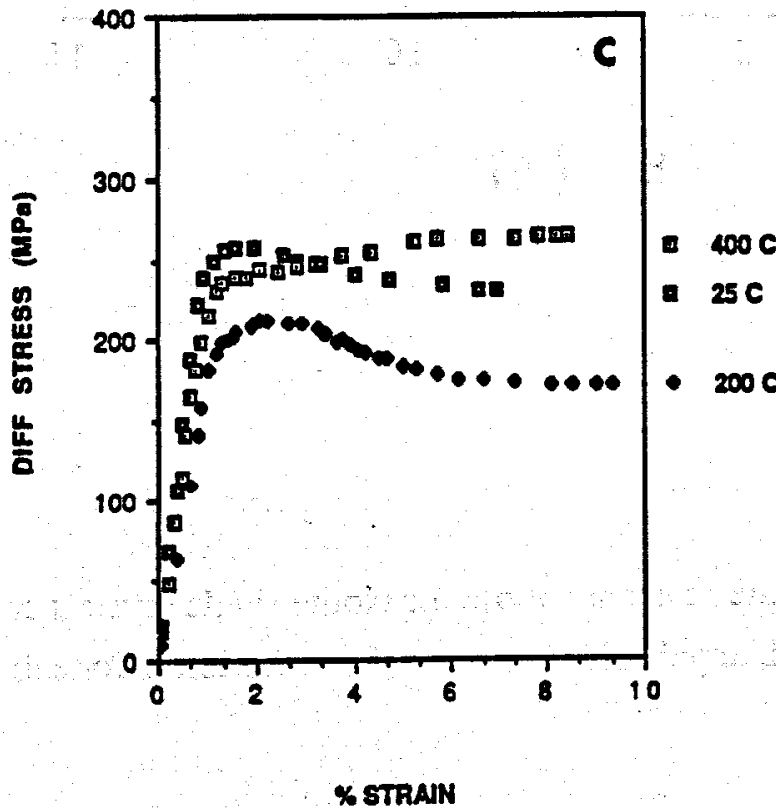

a $25 \mathrm{C}$
S.A. A $S, L=45 / P C=200 \mathrm{MPa}$

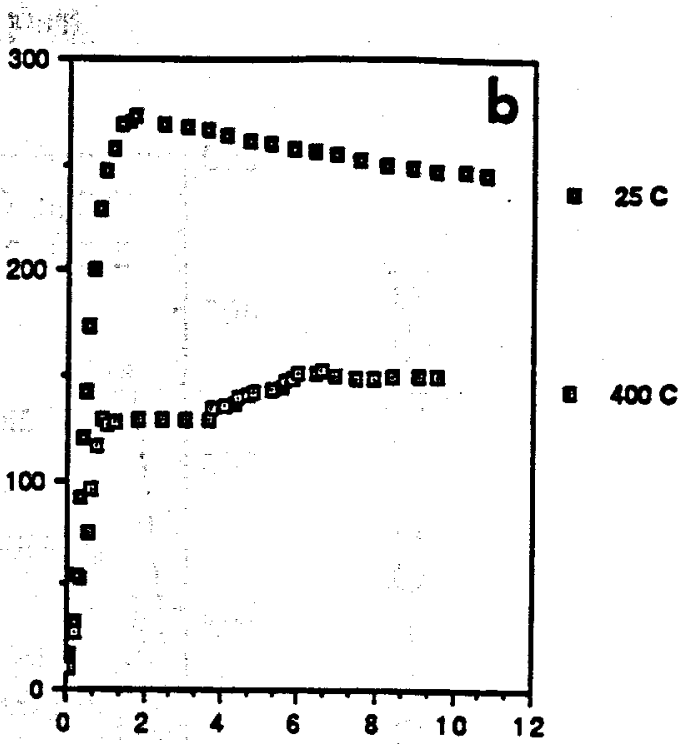

$S A$ A $S, L=45 / P C=300 \mathrm{MPa}$

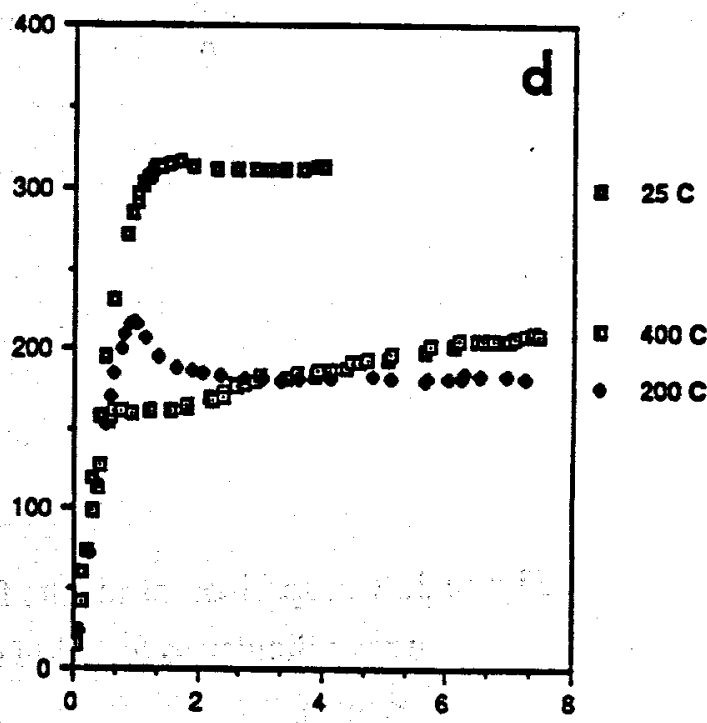

\% STRAN

Figure 2. Stress-strain curves for biotite schist shortened

(a) perpendicular to foliation at $\mathrm{P}_{\mathrm{c}}=200 \mathrm{MPa}, \dot{\varepsilon}=10^{-5} \mathrm{~s}^{-1}$ and $\mathrm{T}=25^{\circ}, 400^{\circ} \mathrm{C}$, (b) at $45^{\circ}$ to foliation and lineation at $\mathrm{P}_{\mathrm{c}}=200 \mathrm{MPa}, \dot{\varepsilon}=10^{-5} \mathrm{~s}^{-1}$ and $\mathrm{T}=25^{\circ}, 400^{\circ} \mathrm{C}$, (c) perpendicular to foliation at $P_{C}=300 \mathrm{MPa}, \dot{\varepsilon}=10^{-5} s^{-1}, T=25^{\circ}, 200^{\circ}, 400^{\circ} \mathrm{C}$, and (d) at $45^{\circ}$ to foliation and lineation at $\mathrm{P}_{\mathrm{c}}=300 \mathrm{MPa}, \dot{\varepsilon}=10^{-5} \mathrm{~s}^{-1}$ and $\mathrm{T}=25^{\circ}, 200^{\circ}$, and $400^{\circ} \mathrm{C}$. 


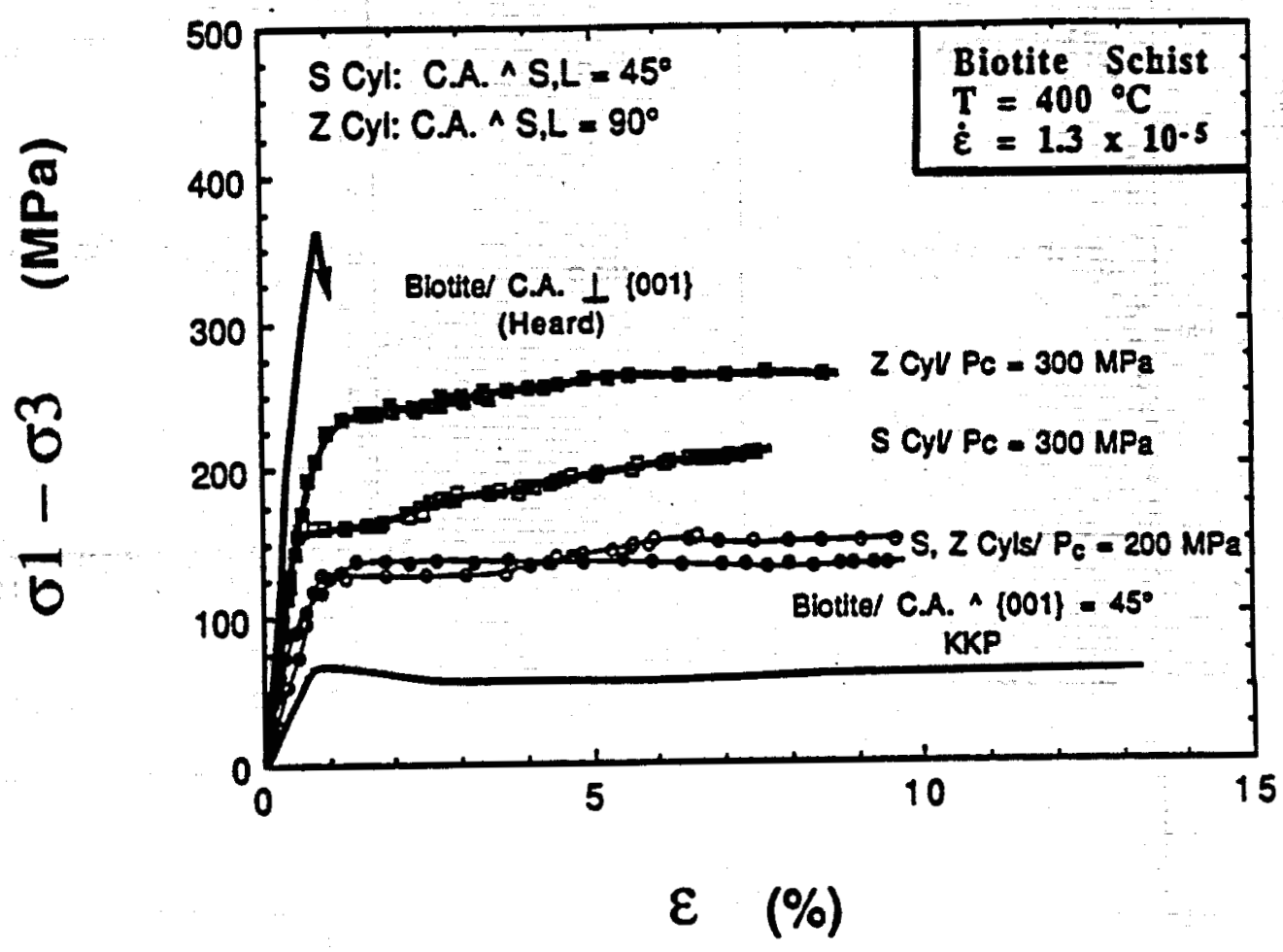

Figure 3. Comparison of results for biotite schist and those for biotite single crystals compressed perpendicular to foliation (Heard, unpublished) and at $45^{\circ}$ to foliation (Kronenberg et al., in review). 
those measured at 2 percent strain). Individual schist samples showed the entire range of behavior from strain hardening, steady strength, and strain softening post-yield behavior, but no systematic response was observed as a function of temperature or confining pressure in either orientation. Differential stresses supported by the schist beyond the yield point lie between those measured for biotite single crystals shortened at $90^{\circ}$ and $45^{\circ}$ to their (001) planes. The results of all of the experiments performed to date are assembled in Table 1.

Compressive strengths of biotite schist exhibit dependencies upon confining pressure as well as upon temperature and strain rate, a result we may expect if deformation is accommodated both by brittle and by ductile processes. Mohr circles representing differential stresses at 2 percent strain have been plotted for samples shortened perpendicular to foliation and at $45^{\circ}$ to foliation (Figure 4) at $T=400^{\circ} \mathrm{C}$ and $\dot{\varepsilon}=10^{-5} \mathrm{~s}^{-1}$. Since the shape of the biotite schist yield envelope cannot yet be determined, we have arbitrarily chosen to fit the plots with linear Mohr envelopes of the form $\tau=$ $S_{\mathrm{o}}+\mu \sigma_{\mathrm{n}}$. Values for $\mu$ range between $0.2 \pm .05$ (shortening axis $S . A . \wedge S, L=45$ ) and $0.3 \pm .05$ (S.A.AS,L = 90), on biotite (001) cleavage surfaces by Horn and Deere (1962). The compressive strengths of biotite schist appear to depend on temperature and strain rate as well, resembling the results for single crystals deformed by dislocation glide (Kronenberg et al., in review) on [001). For example, results of temperature-stepping experiments performed at a confining pressure of 200 MPa and a strain rate of $10^{-5} \mathrm{~s}^{-1}$ (Figure 5) define slopes of $\sim 660 \mathrm{cal} / \mathrm{mol}$ on Arrhenius-type plots of $\ln \left(\sigma_{1}-\sigma_{2}\right)$ versus $1 / T$, remarkably similar to values determined for biotite single crystals (680 $\mathrm{cal} / \mathrm{mol}$ ) oriented favorably for dislocation slip.

Associated with this mechanical behavior, deformed samples exhibit shear zones along which strains have become localized. Shear zones which cross-cut biotite segregations in samples loaded perpendicular to foliation appear wider than those which utilized pre-existing segregation seams in samples loaded at $45^{\circ}$ to foliation. However, in all samples, biotite grains deformed by a combination of kinking, dislocation glide, dilatant microcracking, and frictional gliding on (001). The near-isotropic mechanical response can apparently be explained by the wide distribution of biotite orientations within the matrix, outside of the biotite-rich segregation seams. Although the geometries of the shear zones differ, yielding may begin once the critical resolved shear stresses on $\{001\}$ of some fraction of biotite grains is reached. Chlorite grains are deformed predominantly by basal slip whereas epidote and feldspar grains exhibit dilatant microcracks. Thus, the mechanical response and grain-scale deformation mechanisms are both consistent with deformation in the transitional brittle-ductile field, in which both pressure-sensitive and thermally-activated mechanisms contribute significantly to the deformation.

The transitional brittle-ductile deformation of schist appears to be subject to history-and/or path-dependencies. The results of temperature-stepping experiments differ for those experiments in which the temperature was step-wise increased and decreased (Figure 6) with a change in apparent 
Table 1. Biotite Schist Experiments

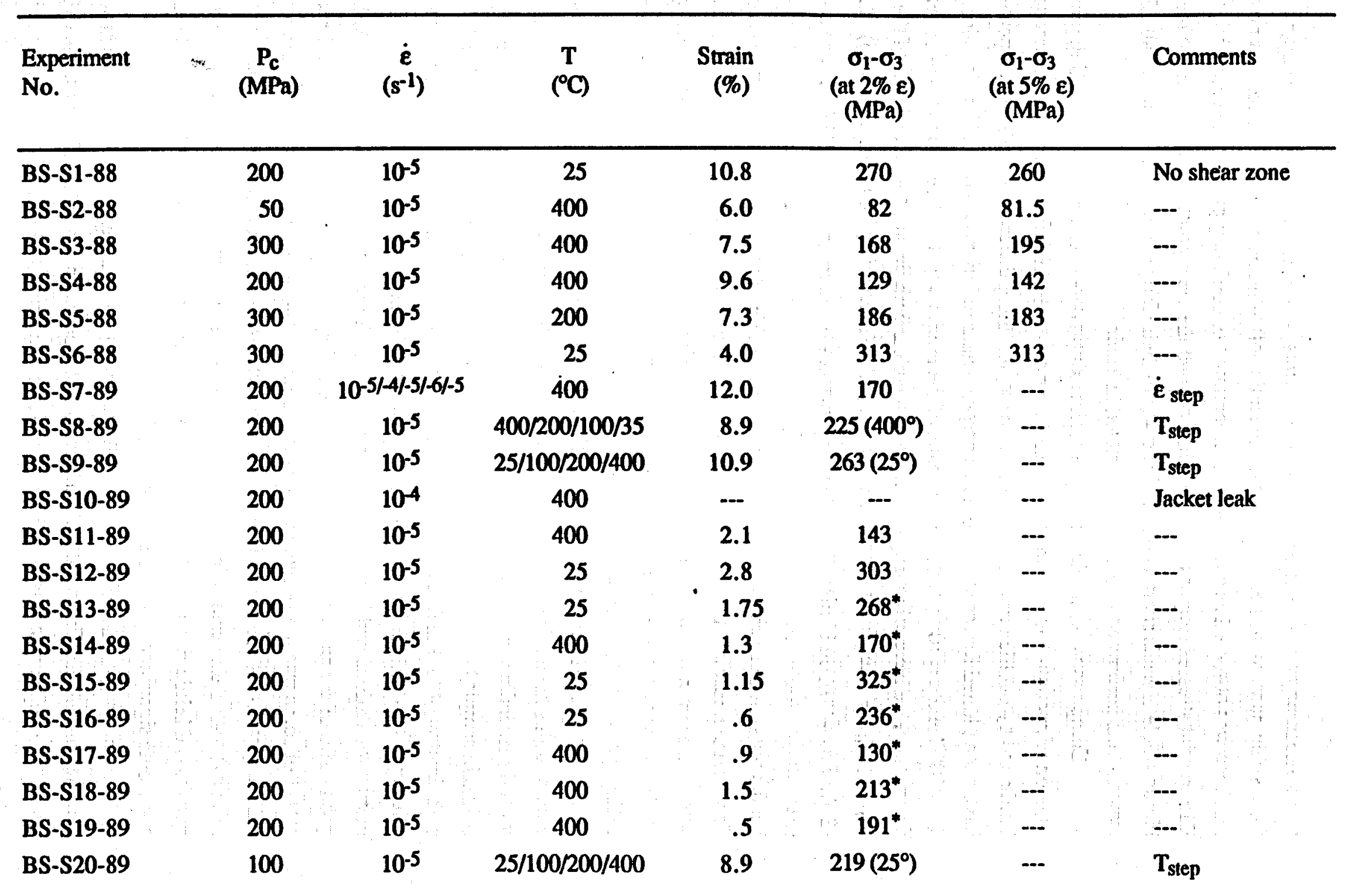


Table 1. Biotite Schist Experiments (continued)

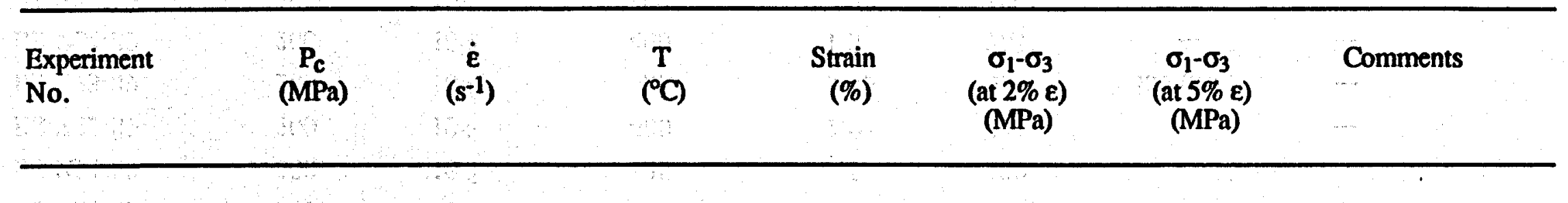

\begin{tabular}{|c|c|c|c|c|c|c|c|}
\hline BS-S21-89 & 300 & $10^{-5}$ & $25 / 100 / 200 / 400$ & 7.7 & $217\left(25^{\circ}\right)$ & --- & $\mathbf{T}_{\text {step }}$ \\
\hline BS-S22-89 & 300 & $10^{-5}$ & $400 / 200 / 100 / 35$ & 8.9 & $249\left(400^{\circ}\right)$ & $\cdots$ & $T_{\text {step }}$ \\
\hline BS-S23-89 & 25 & $10^{-5}$ & 25 & 4.3 & 94 & -- & - \\
\hline BS-S24-89 & 50 & $10^{-5}$ & 25 & 5.7 & 134 & 128 & $\cdots$ \\
\hline BS-S25-89 & 75 & $10^{-5}$ & 25 & 5.7 & 175 & 183 & $\cdots$ \\
\hline BS-S26-89 & .1 & $10^{-5}$ & 25 & 4.0 & 28 & $30 @ 4 \%$ & $\cdots$ \\
\hline BS-S27-89 & 150 & $10^{-5}$ & 25 & 4.8 & 165 & $146 @ 4.8 \%$ & $\cdots$ \\
\hline BS-S28-89 & 150 & $10^{-5}$ & 25 & 4.4 & 256 & $256 @ 4.4 \%$ & $\cdots$ \\
\hline BS-S29-89 & 10 & $10^{-5}$ & 25 & 4.6 & 75 & $54 @ 4.6 \%$ & $\cdots$ \\
\hline BS-Z1-88 & 200 & $10^{-5}$ & 400 & 9.5 & 137 & 137 & -- \\
\hline BS-Z2-88 & 200 & $10^{-5}$ & 25 & 3.0 & 214 & -- & - \\
\hline BS-Z3-88 & 200 & $10^{-5}$ & 25 & 5.0 & 241 & 237 & $\cdots$ \\
\hline BS-Z4-88 & 50 & $10^{-5}$ & 400 & 2.7 & 78 & -- & --- \\
\hline BS-Z5-88 & 300 & $10^{-5}$ & 200 & 9.4 & 212 & 184 & $\ldots$ \\
\hline BS-Z6-88 & 300 & $10^{-5}$ & 400 & 8.4 & 244 & 258 & -- \\
\hline BS-Z7-88 & 300 & $10^{-5}$ & 25 & 6.9 & 256 & 242 & -- \\
\hline BS-Z8-89 & 200 & $10^{-5 /-4 /-5 /-6 /-5}$ & 400 & 9.7 & 241 & 225 & $\dot{\varepsilon}_{\text {step }}$ \\
\hline BS-Z9-89 & 200 & $10-5 /-6 /-5 /-4 /-5$ & 400 & 11.0 & 195 & 208 & $\dot{\varepsilon}_{\text {step }}$ \\
\hline BS-Z10-89 & 200 & $10^{-5}$ & $25 / 100 / 200 / 400$ & 10.1 & $279 @ 25^{\circ}$ & -- & $T_{\text {step }}$ \\
\hline
\end{tabular}


Table 1. Biotite Schist Experiments (continued)

\begin{tabular}{|c|c|c|c|c|c|c|c|}
\hline $\begin{array}{l}\text { Experiment } \\
\text { No. }\end{array}$ & $\underset{(\mathrm{MPa})}{\mathbf{P}_{\mathrm{C}}}$ & $\underset{\left(s^{-1}\right)}{\dot{\varepsilon}}$ & $\begin{array}{c}\mathrm{T} \\
\left({ }^{\circ} \mathrm{C}\right)\end{array}$ & $\begin{array}{c}\text { Strain } \\
(\%)\end{array}$ & $\begin{array}{c}\sigma_{1}-\sigma_{3} \\
(\text { at } 2 \% \varepsilon) \\
(\mathrm{MPa})\end{array}$ & $\begin{array}{c}\sigma_{1}-\sigma_{3} \\
(\text { at } 5 \% \text { e) } \\
(\mathrm{MPa})\end{array}$ & Comments \\
\hline BS-Z11-89 & 200 & $10^{-5}$ & $400 / 200 / 100 / 25$ & 9.9 & $237 @ 400^{\circ}$ & $\cdots$ & $\mathbf{T}_{\text {step }}$ \\
\hline BS-Z12-89 & 200 & $10^{-5}$ & 25 & $\cdots$ & $\cdots$ & -- & Jacket leak \\
\hline BS-213-89 & 200 & $10^{-6 /-5 /-4}$ & 400 & 7.9 & 206 & $\cdots$ & $\dot{\varepsilon}_{\text {step }}$ \\
\hline BS-Z14-89 & 200 & $10^{-5 /-6 /-7}$ & 400 & 10.1 & 211 & - & $\dot{\varepsilon}_{\text {step }}$ \\
\hline BS-Z15-89 & 200 & $10^{-5}$ & 400 & 3.5 & 225 & $210(3.5 \%)$ & $\cdots$ \\
\hline BS-Z16-89 & 200 & $10^{-5}$ & 25 & 2.8 & 299 & $298(2.3 \%)$ & $\cdots$ \\
\hline BS-Z17-89 & 200 & $10^{-5}$ & 400 & 2.3 & 199 & -- & - \\
\hline BS-Z18-89 & 200 & $10^{-5}$ & 25 & 1.7 & $287^{*}$ & - & -- \\
\hline BS-Z19-89 & 200 & $10^{-5}$ & 25 & 1.3 & $311^{*}$ & -- & $\cdots$ \\
\hline BS-Z220-89 & 200 & $10^{-5}$ & 25 & .6 & $240^{*}$ & $\cdots$ & -- \\
\hline BS-Z21-89 & 200 & $10^{-5}$ & 25 & .5 & $220^{*}$ & -- & --- \\
\hline BS-Z22-89 & 200 & $10^{-5}$ & 400 & 2.0 & 241 & $\cdots$ & --- \\
\hline BS-Z23-89 & 200 & $10^{-5}$ & 25 & 3.05 & 355 & $355(3 \%)$ & $\cdots$ \\
\hline BS-Z224-89 & 200 & $10^{-5}$ & 400 & 1.3 & $263^{*}$ & $\cdots$ & --- \\
\hline BS-Z25-89 & 200 & $10^{-5}$ & 400 & .7 & $189^{*}$ & -- & $\cdots$ \\
\hline BS-Z26-89 & 200 & $10^{-5}$ & 400 & 9.7 & 167 & 171 & -- \\
\hline BS-Z27-89 & 100 & $10^{-5}$ & $25 / 100 / 200 / 400$ & 8.7 & $205 @ 25^{\circ}$ & -- & $\mathbf{T}_{\text {step }}$ \\
\hline BS-Z28-89 & 200 & $10^{-5}$ & 400 & Undeformed & -- & -- & Anneal only \\
\hline
\end{tabular}





\section{Effect of Confining Pressure \\ Biotite Schist \\ $\mathbf{T}=400^{\circ} \mathrm{C}$ \\ $\varepsilon=1.3 \times 10^{-5} \mathrm{~s}^{-4}$}

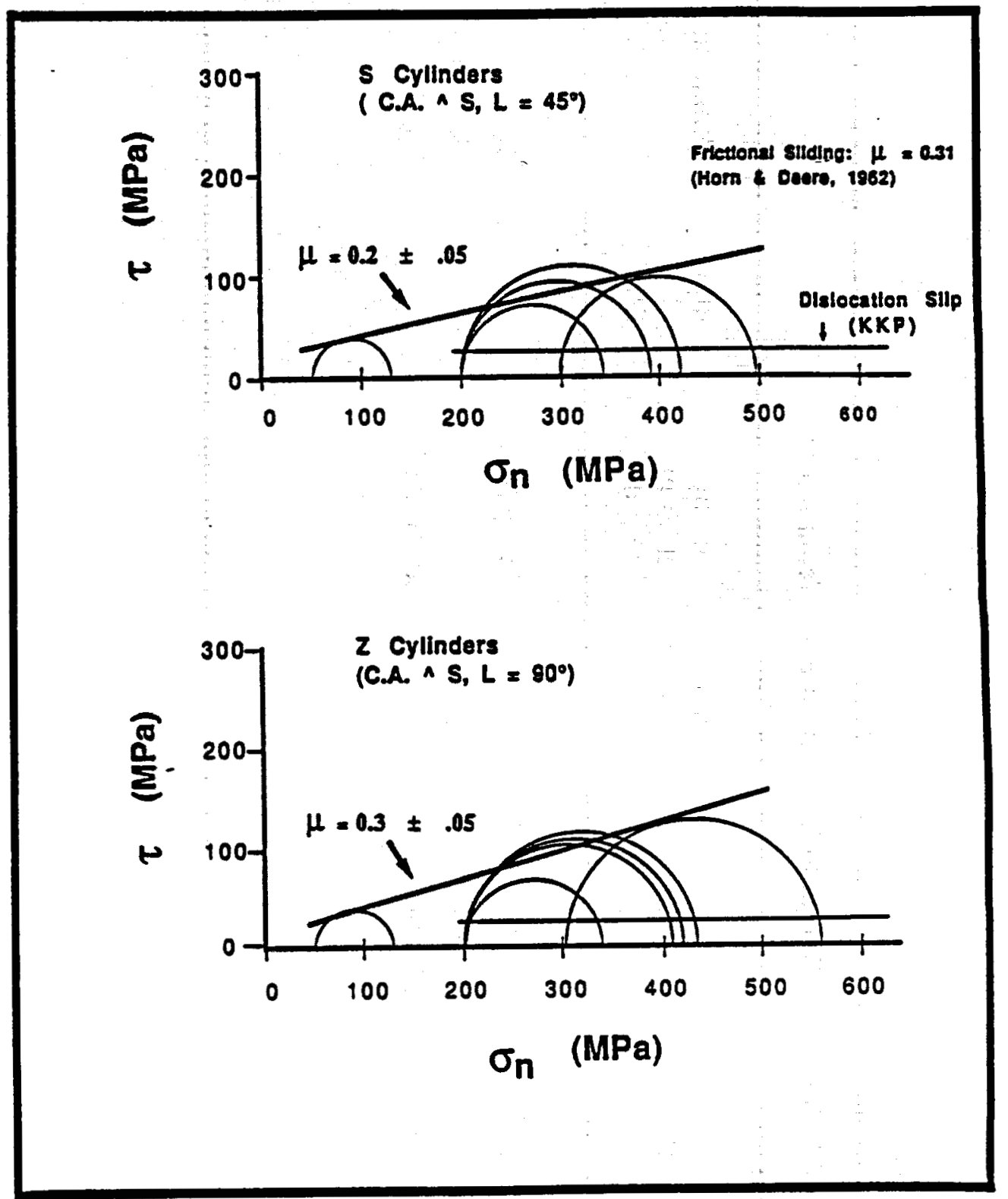

Figure 4. Mohr diagrams of biotite schist data illustrating the effect of confining pressure for (a) samples shortened af $45^{\circ}$ to foliation $S$ and lineation $L$ and (b) samples shortened perpendicular to foliation. 

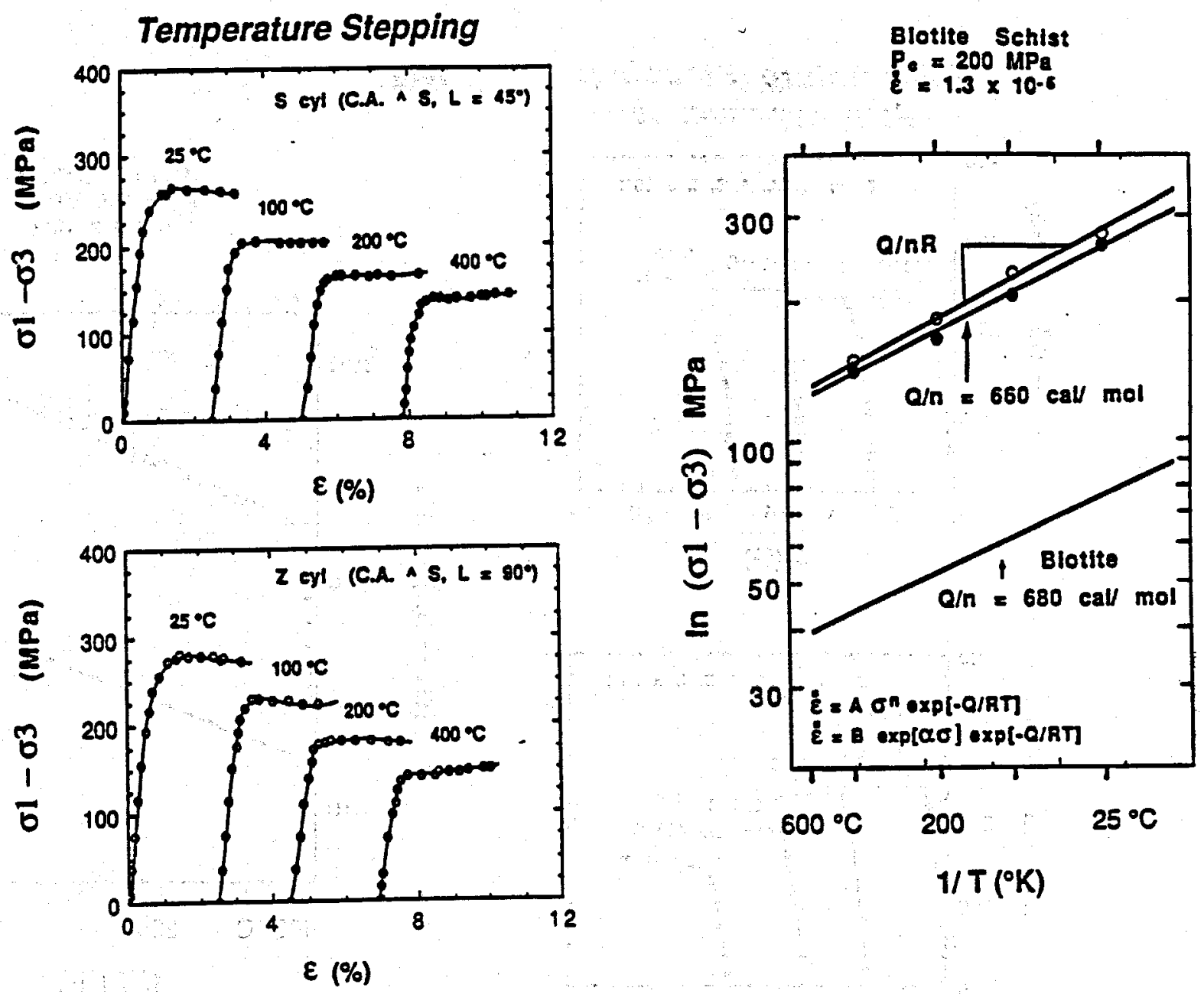

Figure 5. Results of temperarure-stepping experiments performed on biotite schist samples shortened at $45^{\circ}$ and $90^{\circ}$ to foliation. Assuming an Amhenius activation law, the slopes of the schist data represented as $\ln \left(\sigma_{1}-\sigma_{3}\right)$ versus $1 / T$ are nearly the same as that for biotite single crystals deformed by $\{001\}$ dislocation glide. 

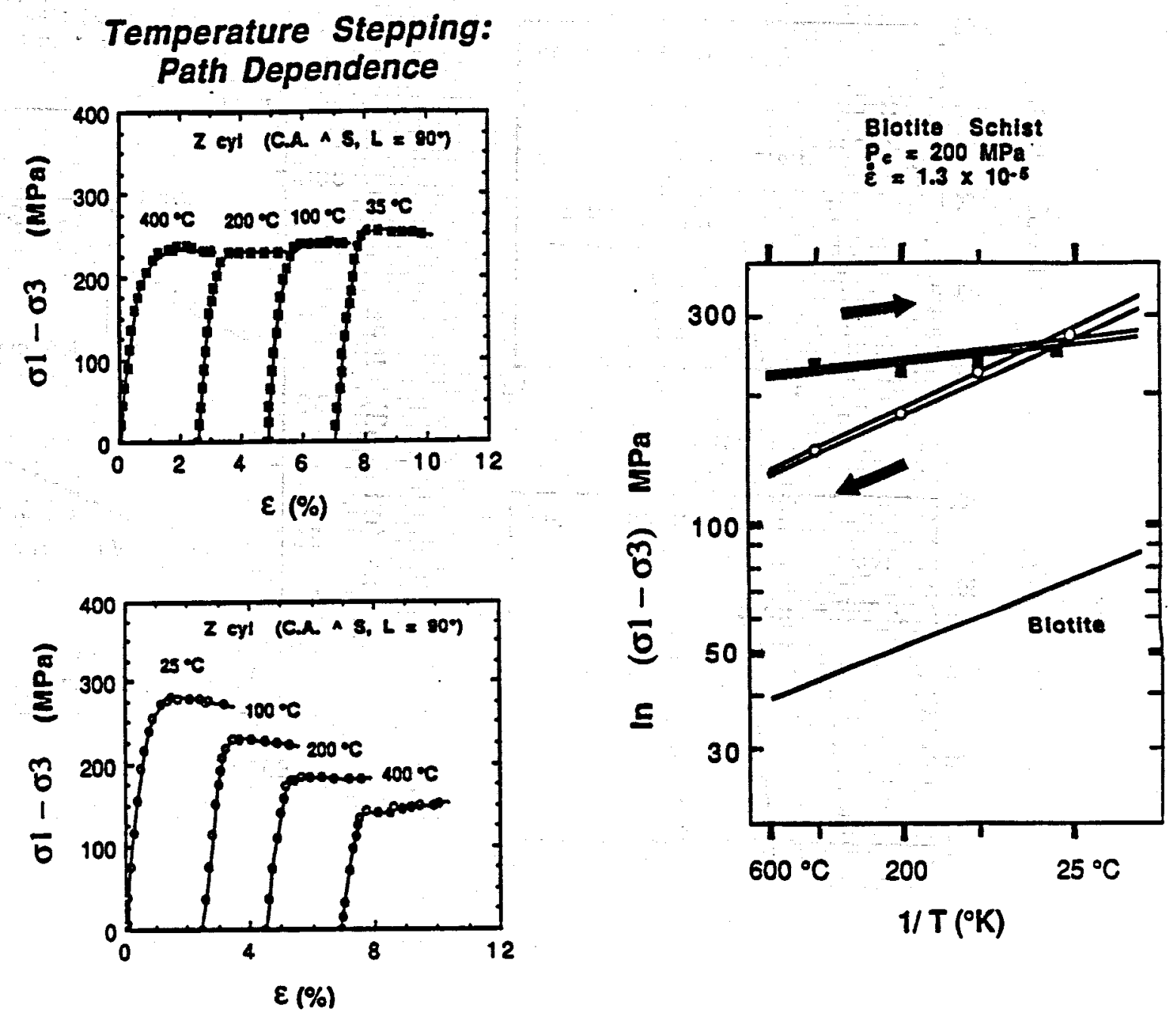

Figure 6. Temperature-stepping experiments showing the path dependence of biotite schist samples shortened at $90^{\circ}$ to foliation. Slopes defined by the data on plots of $\ln \left(\sigma_{1}-\sigma_{3}\right)$ versus $1 / T$ differ systematically depending upon whether temperatures are step-wise increased or decreased. 
activation energy of a factor of $\sim 5$. Similarly, strain rate-stepping experiments have shown that the relationship between differential stress and strain rate is path-dependent, although it has been more difficult to measure.

Both the isotropic nature and path dependence of deformation of the biotite schist chosen for study have been surprising to us, and we have initiated detailed microstructural studies of deformed samples with the goal of understanding the mechanisms of deformation leading to this behavior. In part, we suspect that the mechanical anisotropies of foliated rocks, or lack thereof, may be reflected in the preferred orientations of layer silicates, their spatial distributions, and modal concentrations, and the mechanisms of deformation operative within neighboring phases. Path dependencies may be intrinsic to the processes of dislocation glide, kinking, frictional sliding and microcrack extension of layer silicates, or may reflect changing contributions of these mechanisms to the macroscopic deformation. Our microstructural studies, currently underway, should contribute to our understanding of other foliated and layered rocks as well. Mechanical results for phyllites, slates, and shales have been analyzed only at the macroscopic level due to the extremely fine grain sizes characteristic of these rocks. We propose to continue our study of schist into the next project period treating it as a coarse-grained analogue to fine-grained, clay-bearing shales. We plan experiments on several schists we have collected, with differing mica contents and preferred orientations. By examining their anisotropies and deformation microstructures, we hope to identify those fabric elements which lead to directional behavior. We expect that microstructural and textural studies of fine-grained shales will be more difficult than our studies of schists and we may need to rely on those insights gained from these coarse-grained analogues.

\section{Deformation of Westerly Granite}

For purposes of comparison with Four-Mile gneiss, we performed a series of compression experiments on samples of Westerly granite cored in six orientations with respect to the quarrying planes, the rift $R$, the grain $G$, and the hardway $H$ (Figure 7 ) at confining pressures of 0,50 , and $100 \mathrm{MPa}$. Westerly granite resembles Four-Mile gneiss in composition with similar volume fractions of quartz and feldspars and a combined mica content (7\% biotite and $2 \%$ muscovite) nearly identical to that determined for the gneiss (9\% biotite and $1 \%$ muscovite). In contrast to Four-Mile gneiss, it lacks a distinct foliation due to the wider distribution of mica (001) orientations. Quartz and feldspar grain sizes ( 0.2 to $0.3 \mathrm{~mm}$ ) are somewhat smaller and more uniform than those of Four-Mile gneiss. Microctacks aligned parallel to the rift give rise to variations in acoustic velocities of $\sim 10 \%$ with direction (Krech et al., 1974).

Although granites are commonly assumed to have isotropic mechanical properties, we anticipated that Westerly granite would show a small degree of anisotropy associated with its 

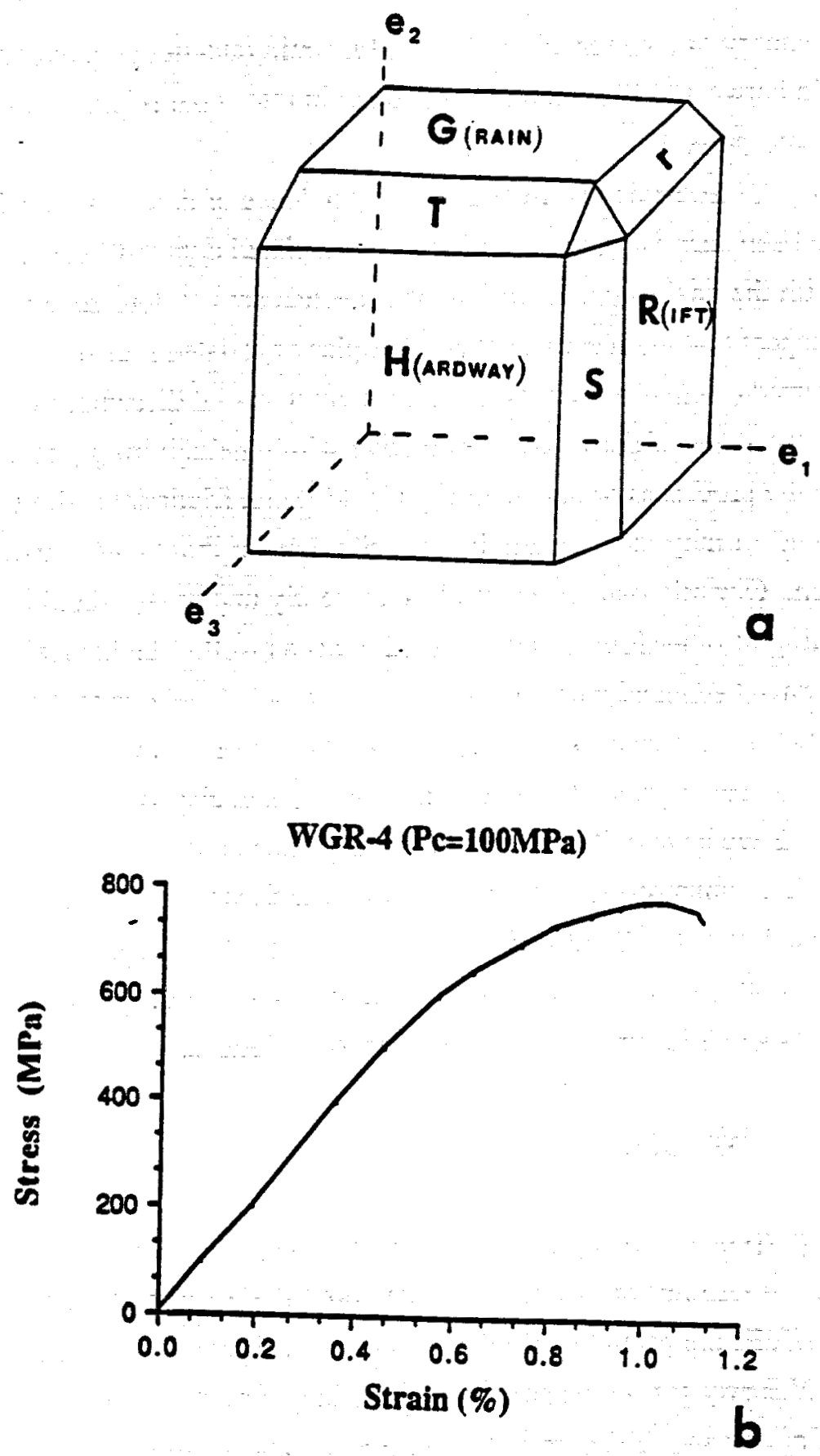

Figure 7. Constant strain rate compression experiments on Westerly granite. (a) Oriented cylindrical samples were prepared by coring perpendicular to the quarrying planes, the rift $R$, the grain $G$, and the hardway $H$, and surfaces prepared at $45^{\circ}$ to $R$ and $G, R$ and $H$, and $G$ and $\mathrm{H}$ (b) Representative stress-strain curve for Westerly granite sample shortened perpendicular to $R$ at $T=25^{\circ} \mathrm{C}, P_{c} 100 \mathrm{MPa}$, and $\dot{\varepsilon}=10^{-5} \mathrm{~s}^{-1}$. 
TABLE 2. WESTERLY GRANITE

\begin{tabular}{|c|c|c|c|}
\hline & confining pressure & ultimate stress & note \\
\hline$\therefore$ & (MPQ) & (MPa) & \\
\hline WGG-1 & 0 & 222.6 & \\
\hline WGG-2 & & $-\infty$ & O-ring failuke \\
\hline WGG-3 & $=$ & & lacket leak \\
\hline WGG-4 & 100 & 672.4 & \\
\hline WGG-5 & 50 & 542.2 & \\
\hline WGT-1 & 0 & 212.2 & \\
\hline WGT-2 & 100 & 800.7 & \\
\hline WGT-3 & 100 & 750.4 & \\
\hline WGT-4 & 50 & 401 & \\
\hline WGT-5 & 50 & 550.7 & initial length about 1.5 \\
\hline WGr-1 & 0 & 165.7 & \\
\hline WGr-2 & 0 & 216.1 & \\
\hline WGr-3 & 100 & 745.3 & initial length about 1.5 \\
\hline WGr-4 & 100 & 665.4 & \\
\hline WGr-5 & 50 & 551.3 & \\
\hline WGH-1 & 0 & 154.9 & \\
\hline WGH-2 & 0 & 218.5 & \\
\hline WGH-3 & 100 & 754 & not perfectly ends \\
\hline WGH-4 & 50 & 563.6 & \\
\hline WGH-5 & 50 & 527 & \\
\hline WGS-1 & 0 & 182.6 & \\
\hline WGS-2 & 0 & 212.3 & \\
\hline WGS-3 & 0 & 185.8 & \\
\hline WGS-4 & 0 & 193.7 & \\
\hline WGS-5 & 100 & 628.1 & initial length about 1.5 \\
\hline WGS-6 & 50 & 500.9 & \\
\hline WGS-7 & 50 & 542.4 & \\
\hline WGS-8 & 50 & 546.1 & \\
\hline WGS-9 & 50 & 344 & \\
\hline WGS-10 & 50 & 411.9 & \\
\hline WGS-11 & 50 & 586.8 & \\
\hline WGS-12 & 50 & 487.6 & \\
\hline WGS-13 & 50 & 578.3 & \\
\hline WGS-14 & 50 & 601.3 & \\
\hline WGS-15 & 50 & 499 & \\
\hline WGS-16 & 50 & 559.7 & \\
\hline WGS-17 & 50 & 500 & \\
\hline WGR-1 & 0 & 175.4 & \\
\hline WGA-2 & 0 & 229.2 & \\
\hline WGR-3 & 100 & 563.8 & jacket leak \\
\hline WGR-4 & 100 & 779.8 & \\
\hline WGR-5 & 50 & 571.2 & \\
\hline WGR-6 & 50 & 563 & \\
\hline WGR-7 & 50 & 462.7 & lacket leak \\
\hline WGR-8 & 50 & 354.1 & \\
\hline WGR-9 & 50 & 448.5 & \\
\hline WGR-10 & 50 & 581.6 & \\
\hline
\end{tabular}




\begin{tabular}{|l|c|l|l|}
\hline WGR-11 & 50 & 606.6 & \\
\hline WGR-12 & 50 & 563.1 & \\
\hline WGR-13 & 50 & 596.1 & \\
\hline WGR-14 & 50 & 557.3 & \\
\hline WGR-15 & 50 & 472.6 & \\
\hline WGR-16 & 50 & 567.2 & \\
\hline
\end{tabular}


preferred orientations of microcracks, similar to the results reported by Peng and Johnson (1972) for Chelmsford granite. Cylindrical samples were prepared and tested in orientations perpendicular to the rift $R$, grain $G$, and hardway $H$, and to surfaces prepared at $45^{\circ}$ to $R, G$, and $H$ (Figure 7). All of the experiments were performed at room temperature and a strain rate of $10^{-5} \mathrm{~s}^{-1}$. All samples failed by fracture and exhibited similar stress-strain curves. However, peak fracture strengths varied from sample to sample by $\sim 14 \%$ and experiments were repeated (as many as 10 times in two orientations).

The results are assembled in Table 2 and indicate that Westerly granite is very nearly isotropic. Unlike the variations in fracture strength of up to $20 \%$ reported for Chelmsford granite (Peng and Johnson, 1972), variations in the compressive strength of Westerly granite with orientation are not detectable over the sample-to-sample variations. Taking mean values of differential stresses measured at failure, Westerly granite samples shortened parallel, perpendicular, and at $45^{\circ}$ to the rift $R$ exhibited strengths of $517( \pm 66) \mathrm{MPa}, 529( \pm 76) \mathrm{MPa}$, and $513( \pm 75)$ $\mathrm{MPa}$, respectively, at a confining pressure of $50 \mathrm{MPa}$.

Petrographic examination of Four-Mile gneiss revealed preferred orientations of intragranular cracks within quartz and feldspars in addition to the crystallographic preferred orientations of micas. However, our results for Westerly granite suggest that preferred orientations of microcracks do not affect anisotropy of quartz-feldspathic rocks nearly as much as do mica preferred orientations.

\section{Deformation of Bedded Rocksalt}

Under supplemental funding from the Department of Energy, we have performed experiments on coarse-grained bedded salt samples cored in three orientations with respect to the bedding plane. The results of experiments performed to date at $\mathrm{T}=25^{\circ} \mathrm{C}, \mathrm{P}_{\mathrm{C}}=15 \mathrm{MPa}$, and $\dot{\varepsilon}=$ $10^{-4} \mathrm{~s}^{-1}$, and at $\mathrm{T}=200^{\circ} \mathrm{C}, \mathrm{P}_{\mathrm{c}}=15 \mathrm{MPa}$, and $\dot{\varepsilon}=10^{-6} \mathrm{~s}^{-1}$ are shown in Figure 8 and assembled in Table 3 for samples shortened perpendicular to bedding (labeled V), parallel to bedding (labeled $\mathrm{H}$ ), and at $45^{\circ}$ to bedding (labeled 45). Differential stresses measured in these three orientations are indistinguishable within the experimental uncertainties. However, significant differences have been observed in the lateral strains of these samples, which suggest subtle departures from isotropic mechanical properties (Figures 9 and 10).

Due to the power law relationship between the differential stress and strain rate (i.e., with $\mathbf{n}$ $=4.5$ ) in the constitutive equation for rocksalt, differing strain rates in directions normal to the imposed shortening direction may provide a more sensitive measure of anisotropy than do comparisons of differential stresses for samples shortened in differing directions with respect to bedding. Differing strain rates normal to the shortening direction should be reflected in differing final lateral strains. For example, the final state of stress obtained in experiment $103\left(\mathrm{~T}=200^{\circ} \mathrm{C}, \mathrm{P}_{\mathrm{c}}\right.$ 

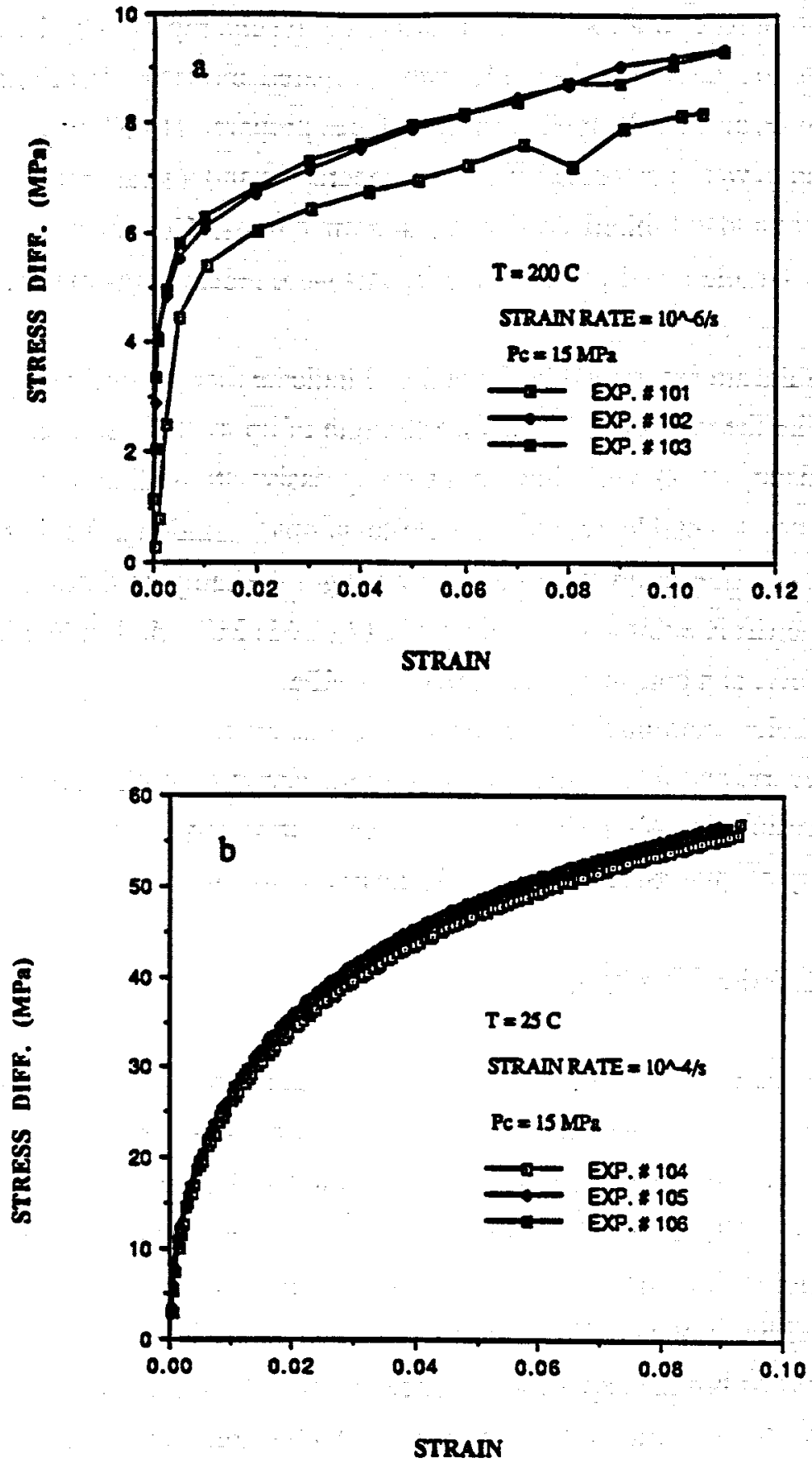

Figure 8. Differential stress versus strain for bedded rocksalt samples deformed at (a) $T=200^{\circ} \mathrm{C}, \mathrm{P}_{\mathrm{c}}$ $=15 \mathrm{MPa}$, and $\dot{\varepsilon}=10^{-6} \mathrm{~s}^{-1}$, and at (b) $\mathrm{T}=25^{\circ} \mathrm{C}, \mathrm{P}_{\mathrm{c}}=15 \mathrm{MPa}$, and $\dot{\varepsilon}=10^{-4} \mathrm{~s}^{-1}$. Samples 101 and 104 were shortened along their cylindrical axes, prepared perpendicular to bedding. Samples 103 and 106 were shortened parallel to bedding, and samples 102 and 105 were shortened at $45^{\circ}$ to bedding. 
Table 3. Bedded salt experimental results for three orientations vertical (V), 45 degrees from horizontal (45), and horizontal (H).

\begin{tabular}{|c|c|c|c|c|c|}
\hline Exp. \# & $\varepsilon \operatorname{Max}$. & $\begin{array}{c}\sigma @ 10 \% \varepsilon \\
(\mathrm{MPa})\end{array}$ & $\begin{array}{c}\sigma @ \varepsilon \operatorname{Max} . \\
(\mathrm{MPa})\end{array}$ & Orientation & Conditions \\
\hline 101 & 0.108 & 8.12 & 8.23 & v & $\mathrm{T}=200^{\circ} \mathrm{C}$ \\
\hline 102 & 0.111 & 9.21 & 9.35 & 45 & $\dot{\varepsilon}=10^{-6} \mathrm{~s}^{-1}$ \\
\hline 103 & 0.111 & 9.10 & 9.33 & H & $\mathrm{P}_{\mathrm{c}} 15 \mathrm{MPa}$ \\
\hline Exp.\# & $\varepsilon$ Max. & $\begin{array}{c}\sigma @ 9 \% \varepsilon \\
\text { (MPa) }\end{array}$ & $\begin{array}{c}\sigma @ \varepsilon \operatorname{Max} . \\
(\mathrm{MPa})\end{array}$ & Orientation & Conditions \\
\hline 104 & 0.091 & 55.2 & 55.4 & v & $\mathrm{T}=25^{\circ} \mathrm{C}$ \\
\hline 105 & 0.089 & 56.6 & 56.6 & 45 & $\dot{\varepsilon}=10^{-4} s^{-1}$ \\
\hline 106 & 0.091 & 56.2 & 56.4 & $\mathbf{H}$ & $P_{c}=15 \mathrm{MPa}$ \\
\hline
\end{tabular}



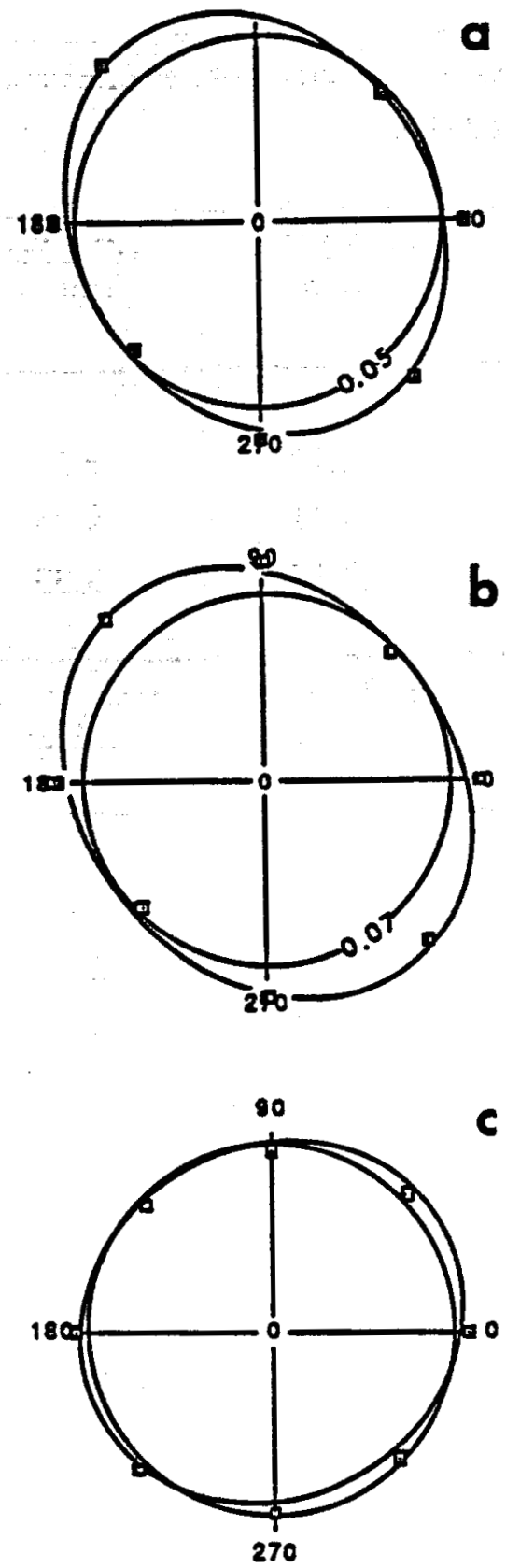

Figure 9. Lateral strains determined from measurements of initially cylindrical rocksalt samples shortened along their axes, with uniformly applied lateral pressures $P_{c}$. Bedded rocksalt samples 106 (a) and 103 (b) shortened perpendicular to bedding at $T=25^{\circ} \mathrm{C}, P_{c}=15 \mathrm{MPa}$, and $\dot{\varepsilon}=10^{-4} \mathrm{~s}^{-1}$ and at $\mathrm{T}=200^{\circ} \mathrm{C}, \mathrm{P}_{\mathrm{c}}=15 \mathrm{MPa}$, and $\dot{\varepsilon}=10^{-6} \mathrm{~s}^{-1}$, respectively, exhibit strain ellipses with consistent major and minor axes with respect to material coordinates. (c) Measurements of Avery Island rocksalt samples reveal lateral strains which are more nearly isotropic (Avery Island sample \# 12 shortened at $\mathrm{T}=200^{\circ} \mathrm{C}, \mathrm{P}_{\mathrm{c}}=20 \mathrm{MPa}$, and $\dot{\varepsilon}=10^{-6} \mathrm{~s}^{-1}$ ). All measurements were made midway between the sample ends. Circles represent constant magnitudes of lateral strains. 

$=15 \mathrm{MPa}_{,} \dot{\varepsilon}=10^{-6} \mathrm{~s}^{-1}$ ) may be expressed in material coordinates (where $\mathrm{z}$ is chosen perpendicular to bedding):

$$
\sigma_{\mathrm{ij} \text { (fina) }}=\left[\begin{array}{ccc}
15.00 & 0 & 0 \\
0 & 15.00 & 0 \\
0 & 0 & 24.33
\end{array}\right] \mathrm{MPa}
$$

whereas the permanent finite strain near the sample's center may be approximated:

$$
\varepsilon_{\mathrm{ij}} \text { (permanent) }=\left[\begin{array}{ccc}
-0.071 & 0 & 0 \\
0 & -0.088 & 0 \\
0 & 0 & 0.159
\end{array}\right] \mathrm{MPa}
$$

assuming strains are sufficiently small to treat them as infinitesimal and neglect errors associated with their measurement as engineering strains. We believe that these preliminary results are promising and we will continue investigating the weakly-defined anisotropy of bedded rocksalt until the end of the current project period.

\section{Abstracts}

Gottschalk, R. R. and A. K. Kronenberg, Anisotropic yielding of gneiss: influence of foliation and lineation, EOS Trans. AGU, 69, 474, $1988 \mathrm{.}$

Gottschalk, R. R, and A. K. Kronenberg, Experimental deformation of gneiss: influence of phyllosilicates on fracture mechanisms and anisotropic yielding, Geol. Soc. Am. Abstracts with Programs, 20, A213, 1988b.

Shea, W. T., A. K. Kronenberg, and B. G. Erskine, Diapiric emplacement of granitic magma: a natural example, Geol Soc. Am. Abstracts with Programs, 20, A272, 1988.

Russell, J. E., and R. R. Gottschalk, Anisotropic yielding of Gneiss: modeling of room temperature results, EOS Trans. AGU 70, 477, 1989.

Shea, W. T., and A. K. Kronenberg, Experimental deformation of biotite schist, EOS Trans. AGU, 70, 477,1989 a.

Shea, W. T., and A. K. Kronenberg, Path-dependent, brittle-plastic flow of biotite schist, EOS Trans. AGU, 70, 1364-1365, 1989b. 


\section{Students Supported}

Three students in the Center for Tectonophysics have received support from this grant in the form of research assistantships. William Shea has been involved in the work on biotite schist and is expected to complete his Ph.D. thesis on "The Roles of Micas and Fabric in the Deformation of Foliated Rock: An Experimental Study" within the upcoming year. Lin Peng performed the granite experiments and is expected to complete her M.S. thesis on "The Interaction of Two Closely Spaced Cracks-Rock Models and Computer Simulations" by the end of May, 1990. Michael Tsenn has been involved in the work on salt deformation and has made excellent progress on his $\mathrm{Ph}$.D. research, including experimental and observational results.

Richard Gottschalk received support from this grant in the form of a postdoctoral fellowship. In addition to completing a thorough investigation of Four-Mile gneiss, Rick effectively extended his education in structural geology and tectonics to include a solid background in mechanics. 